\title{
Wartime Nostalgia in Italy: Validating the Fatherland
}

\author{
Guy Lanoue \\ Département d'anthropologie, Université de Montréal \\ guy.lanoue@umontreal.ca
}

\begin{abstract}
In the late 1980 s and early 1990 s, Italy experienced a series of crises when its precarious postwar political compromise was challenged by the effects of decades of structural corruption. The author was offered unsolicited narratives of the prewar and especially wartime Fascist period. Surprisingly, many of these stories cast Fascists and their Nazi political allies in a positive light. Here, the author argues that these favourable views of a bleak period are linked to the disenchantment and diffidence many felt (and continue to feel) toward the state and its institutions, and that these stories are not nostalgic expressions of fascist sympathies. Instead, they stress how people managed the micro-details of everyday life to gain small, individual victories against wartime degradations that would otherwise transform them into powerless victims. Even today, these expressions of individual agency reinforce shared notions that there is alternative to the institutional culture of an inefficient and oppressive state.
\end{abstract}

\section{Keywords}

Italy - Fascism - nostalgia - Second World War - fatherland - oral history

Odysseus' ten-year homeward journey tells a tale of longing for a past that seems to him increasingly unattainable with each adventure in a distant land. Beyond the personal emotions of Odysseus' sense of loss, there is also a social dimension: nostalgia is a narrative device that heightens the story's climax, when Odysseus kills Penelope's suitors and executes his servants for disloyalty.

(C) GUY LANOUE, $2019 \mid$ DOI:10.1163/22116257-00801005

This is an open access article distributed under the terms of the prevailing CC-BY-NC license at the time of publication. 
Homer thus established the trope ${ }^{1}$ that the present and past are different worlds that can only be harmonised by violently refashioning one or the other, either by extirpating elements from the present or by (re)inventing the past. Nostalgia softens the jarring discontinuities of the present with the simulacrum of an imagined and idealised past; when it becomes rooted in the culture, it is 'structural nostalgia', in Michael Herzfeld's words. ${ }^{2}$ Here I argue that under some circumstances, disjunctions in Italian history are not eliminated (like Penelope's suitors) but are exploited to create a functional personal identity that references the arts of living, civiltà, as an antidote to state sponsored failures to create a meaningful community defined and framed by its institutions.

In particular, I examine some nostalgic accounts ${ }^{3}$ of one of the bleakest periods in Italian recent history, the Fascist ventennio (1922-1943) and the wartime German occupation of Rome that followed. Unlike Germans and Japanese examined by Buruma, ${ }^{4}$ who have distanced themselves from their wartime fascism either by highly public and somewhat ritualised affirmations of guilt or by overwhelming silence, Italians have hesitated to embrace fully either option, leaving the issue of fascism and national identity somewhat ambiguous. This, I argue, came at a time - the last two decades or so of the twentieth century - when Italian postwar political culture was under fire from the very corruption it had engendered, leading to uncertainty and social tension, not to mention the rise of regional parties (usually in the north) whose nationalistic agendas had some xenophobic overtones that were underscored by their appeals to an allegedly uncorrupt and a-political past. ${ }^{5}$ In brief, many issues remained unresolved, and nostalgia for wartime and its Fascist associations continues to animate some contemporary political movements such as

1 See the review of a 2008 conference on nostalgia, where literary uses and issues as a trope far outweigh its use in the analysis of memory dynamics; Jeremy Davis, 'Nostalgia and the Shapes of History: A conference held at Queen Mary, University of London, 13-14 June 2008,' Memory Studies 2 (2009): 123-125, https://doi.org/10.1177/1750698008097400.

2 Michael Herzfeld, Cultural Intimacy: Social Poetics in the Nation-State (Routledge: New York, 1997), 109.

3 Seven of these accounts can be found at: http://mapageweb.umontreal.ca/lanoueg/ LANOUE/lecons/nostalgia\%2oaccounts.pdf.

4 Ian Buruma, 'Entre honte et culpabilité: Le souvenir de la guerre chez les Allemands et les Japonais,' Vingtième Siècle: Revue d'histoire 39 (1993): 72-78.

5 Jaro Stacul, 'Natural Time, Political Time: Contested Histories in Northern Italy,' The Journal of the Royal Anthropological Institute 11 (2005): 819-836. 
CasaPound Italia ${ }^{6}$ and cultural reference points such as the Vittoriale degli Italiani, Gabriele D'Annunzio's home to his vast collections of allegorical memorabilia transformed into a popular (over 200,000 visitors a year) museum in 2000.

I am not arguing that these and other contemporary phenomena are inspired by fascist ideologies or by a desire to put in place fascist solutions to contemporary problems. I argue that the hundreds of wartime nostalgia narratives I collected between 1987 and late 2001 (and later, though in a more sporadic version $)^{7}$ were constructed in such a way that they not only reinforced the emotional substrate of the self buffeted by the political storms of the contemporary nation, but were also a means of distancing the individuals who share such stories from a dysfunctional political community by making claims to membership in the patria, the fatherland, a community of everyday values that Italians recognise as an alternative to the inefficient and corrupt state. ${ }^{8}$ I show that the emotional warmth and security of wartime solidarity that run through standard wartime nostalgia narratives are absent in these mini-dramas. While it might seem obvious that more or less ordinary upper middle-class people whose stories I recorded should identify with the institutional guarantor of their status, the opposite is true. They reveal an unusual quality: Fascists and their German allies played positive roles in validating postwar status and identity that are normally performed by institutions. Ironically, widespread postwar reluctance to engage in a public debate about the cultural significance of the Fascist period in some ways allowed some people to view their personal situations in ideological terms. In the stories I collected, Fascists and Nazis, who are now anathema in official history and in public discourse, are given key roles as enablers and validators of the small details that define the self in ways that allowed people to establish some distance from the state's convoluted political culture. In this sense, as Nelis has pointed out, ${ }^{9}$ Fascist culture was not only obsessed with the past but provided a framework for the future. Behind the 'stories' I recorded is an assumption that these memories, although constructed for and filtered through the prism of the present, are not mere stories,

6 Pietro Castelle Gattinara, Caterina Froio and Matteo Albanese, 'The Appeal of Neo-Fascism in Times of Crisis: The Experience of CasaPound Italia,' Fascism 2 (2013): 244, https://doi .org/10.1163/22116257-00202007.

7 About half of the conversations were offered spontaneously in the context of other conversations, while the other half were voiced during formal interviews.

8 See, for example, Castellanos, who describes how residents of Bergamo identify more with the local, intimate community than with the nation; Erick Castellanos, 'The Symbolic Construction of Community in Italy: Provincialism and Nationalism,' Ethnology 49 (2010): 61-78.

9 Jan Nelis, 'Back to the Future: Italian Fascist Representations of the Roman Past,' Fascism 3 (2014): 19, https://doi.org/10.1163/22116257-00301001. 
as Leavitt points out, ${ }^{10}$ memories may be about the present in some sense but they are seen as constitutive of the past self. Neither a record nor a mere narrative performance, memories present themselves as, 'real lived experience'11 and thus can easily frame jarring aspects of the present.

There is a tendency to see nostalgia as a rosy longing for the past, though this lament for things lost cannot express the complex dimensions of how the past intersects the present, as Pickering and Keightley argue. ${ }^{12}$ Eighteenth and nineteenth century views on nostalgia tended to see it as a disruptive or even anarchistic phenomenon, a threat to military discipline and to social order. ${ }^{13}$ In the early twentieth century, it was regarded as a psychiatric disorder ${ }^{14}$ or, later, as a symptom of depression, an unwillingness to engage with the present. Towards the end of the century, researchers began to realise that there were other aspects to nostalgia, especially a desire to evoke positive associations to one's past. These emotions are not limited to 'home' except in the widest metaphorical sense; for example, a return to certain conditions of childhood, especially its well-ordered simplicity and happiness. In this optic, nostalgia can be centred on childhood games and toys, first loves, family vacations or other happy moments that are generally interpreted as contributing to the formation of the healthy adult self. In other words, nostalgia came to be seen as a source of positive reinforcement that could help integrate the self when faced with chaos or absurdity. ${ }^{15}$ This is much the same process that has been attributed to autobiographical memory, ${ }^{16}$ though these latter researchers note

$10 \quad$ John Leavitt, 'Review: Tense Past: Cultural Essays in Trauma and Memory by P. Antze and M. Lambek,' Anthropologica 43 (2001): 279-280.

11 Leavitt, 'Review,' 279-280.

12 Michael Pickering and Emily Keightley, 'The Modalities of Nostalgia,' Current Sociology 54 (2006): 920, https://doi.org/10.1177/oo11392106068458.

13 N. Naqvi, 'The Nostalgic Subject: A Genealogy of the "Critique of Nostalgia",' CIRSDig Working Paper no. 23, Quaderni della Sezione: Diritto e Comunicazioni Sociali (2007), accessed April 14, 2015, http://www.cirsdig.it/Pubblicazioni/naqvi.pdf.

14 Constantine Sedikides et al, 'Nostalgia: Past, Present, and Future,' Current Directions in Psychological Science 17 (2008): 304, https://doi.org/10.1111/j.1467-8721.2008.00595.x.

15 Clay Routledge et al, 'The Power of the Past: Nostalgia as a Meaning-Making Resource,' Memory 20 (2012): 452-46o, https://doi.org/10.1080/o9658211.2012.677452.

16 Tilmann Habermas and Christin Köber, 'Autobiographical Reasoning in Life Narratives Buffers the Effect of Biographical Disruptions on the Sense of Self-Continuity,' Memory 23 (2014): 664-674, https://doi.org/10.1080/09658211.2014.920885. 
that the integrative function seems to increase with age; in other words, they claim there is more 'narrative' and less 'memory' as one's sense of self-identity becomes consolidated over time.

Evolving notions of 'home' also redefined nostalgia. In the late twentieth century, increasingly porous frontiers around self and nation meant that 'home' acquired more and more characteristics drawn from imagined communities. This complicated discussions of the past as a source of psychic reinforcement. Some researchers argued that the comfort of nostalgia rests on two assumptions: naiveté, or a discrepancy between the knowledge of the past and the present; and the 'poverty of the present,', ${ }^{17}$ where the past is seen as preferable to the present. In fact, allegedly naïve memories of the past are not based on ignorance but on selection, which may not always be triggered by disappointment with the present. For example, Howard argues that Proustian nostalgia is involuntary (referring to the famous episode of tea and madeleines in À la recherché du temps perdu) and hence cannot be interpreted as necessarily motivated by the failure of the present. Furthermore, Wildschut ${ }^{18}$ found that nostalgia narratives were not always rosy and sometimes contained elements of sadness; these, however, were outweighed by positive emotions linked to redemptive interpretations that recast sad events (loss, funerals, etc.) to produce feelings of acceptance, euphoria and triumph, ${ }^{19}$ or helped reinforce the Self overwhelmed by loneliness, ${ }^{20}$ or simply functioned as a positive resource for constructing a coherent portrait of the self. ${ }^{21}$ Finally, although it seems obvious that nostalgia should be linked to age and ageing as people lose bodily, social and psychic power, this is not explicitly mentioned in most studies. Exceptions are analyses of consumption patterns motivated by or at least attached to nostalgia, since marketers are long-used to distinguishing consumers by age as well as by class and geography. ${ }^{22}$

17 Scott A. Howard, 'Nostalgia,' Analysis 72 (2012): 642, https://doi.org/10.1093/analys/ans105.

18 Tilmann Wildschut et al, 'Feeling Happy and Sad at the Same Time: Nostalgia Informs Models of Affect,' (Albuquerque: gth Annual Meeting of the Society for Personality and Social Psychology, 2008), cited in Sedikides, 'Nostalgia,' 304.

19 D.P. McAdams, 'The Psychology of Life Stories,' Review of General Psychology 5 (2001):100112, cited in Sedikides, 'Nostalgia,' 305.

$20 \quad X$. Zhou et al, 'Counteracting Loneliness: On the Restorative Function of Nostalgia,' Psychological Science 19 (2008): 1023-1029.

21 M. Vess et al, 'Nostalgia as a Resource for the Self,' Self and Identity 11 (2012): 273-284.

22 M.B. Holbrook, 'Nostalgia and Consumption Preferences: Some Emerging Patterns of Consumer Tastes,' Journal of Consumer Research 20 (1993): 245-256; D.D. Muehling and D.E. Sprott, "The Power of Reflection: An Empirical Examination of Nostalgia Advertising Effects,' Journal of Advertising 33 (2004): 25-35; J.J. Sierra and S. McQuitty, 'Attitudes and Emotions as Determinants of Nostalgia Purchases: An Application of Social Identity 
Whether positive or negative, triggered inadvertently or by a desire to escape an imperfect present, nostalgia is not only about how bittersweet narratives redeem the Self. It is another skirmish in the time wars that have dominated contemporary western societies since the nineteenth century, when modern states began underwriting linear, future-oriented histories in classrooms and in other institutional venues. ${ }^{23}$ Nostalgia is about shared history as much as it is about a private past, as research on advertising acknowledges. ${ }^{24}$ It is, 'the desire not to return but to recognize aspects of the past as the basis for renewal and satisfaction in the future.25 Some contemporary states, however, can demonise the past, as Gotfredsen shows in the context of post-Soviet Georgia. In an attempt to make a clean break and legitimate the new regime, Georgia's Soviet past has, 'been silenced and rendered void', forcing people to nurture Soviet-era memories to recover their personal pasts that were forged under the old regime. ${ }^{26}$

In brief, it may be that the academic shift that sees nostalgia as a motor for connectedness is a mirror of recent developments in the West where stronger neoliberal individuality unconsciously urges people to create virtual substitutes for friable communities, or is an acknowledgement that modernity has transformed people's experience of time, such that it, 'leaves no space, remedial or otherwise, for dealing with the experience of loss.. ${ }^{27}$ Nor is it surprising that

Theory,' Journal of Marketing Theory and Practice 15 (2007): 99-112; though see Reid, whose research on scent-induced nostalgia could be an indication that nostalgia is agespecific, although all their test subjects were university undergraduates: Chelsea A. Reid et al, 'Scent-evoked nostalgia,' Memory 23 (2015): 157-166, https://doi.org/10.108o/o96582 11.2013 .876048 .

23 For example, Fritzsche writes, 'nostalgia is a fundamentally modern phenomenon because it depended on the notion of historical process as the continual production of the new.' Peter Fritzsche, 'Specters of History: On Nostalgia, Exile, and Modernity, The American Historical Review 106, no. 5 (2001): 1589. Nostalgia is not a rupture in time, but 'discontinuities' (Ibid.:1595) in historical, state time. '[I]t was in the middle of the nineteenth century that nostalgia found a secure place in household vocabularies, its general usage made tenable by the massive displacing operations of industrialisation and urbanisation, which also standardised its meaning as a vague, collective longing for a bygone time rather than an individual desire to return to a particular place. Nostalgia retains this general and temporal meaning; it distills the 'dispirit of the age.' (Ibid.:1591).

24 D.D. Muehling and V.J. Pascal, 'An Empirical Investigation of the Differential Effects of Personal, Historical, and Non-Nostalgic Advertising on Consumer Responses,' Journal of Advertising 40 (2011): 107-122.

25 Pickering and Keightley, 'The Modalities of Nostalgia,' 921.

26 Katrine Bendtsen Gotfredson, 'Void Pasts and Marginal Presents: On Nostalgia and Obsolete Futures in the Republic of Georgia', Slavic Review 73 (2014): 247, 249.

27 Pickering and Keightley, 'The Modalities of Nostalgia,' 928. 
many studies have tended to focus on sites where a theatrically-staged political rupture with communism, such as in many Eastern European countries, ${ }^{28}$ establishes easily-accessed pathways to the halcyon days when past regimes allegedly guaranteed peace and order that stand in contrast to the post-socialist confusion. On the other hand, Naqvi rightly warns ${ }^{29}$ that nostalgia can be in the service of state disciplinary power when it establishes that feelings of 'loss' harken to an unsanctioned, individual view of the past at odds with state insistence on forward-looking ideologies. ${ }^{30}$ Both positions have merit, since these feelings can mobilise individual strategies of resistance and affirmation.

In the 1990s, I began researching the meaning of Rome's 'eternal' identity tag. What did 'Rome Eternal' mean to Romans in light of Rome's tumultuous history that has continually transformed the city? My status as a foreign-born but long-time resident of Rome allowed me to question hundreds of people about Rome and its relation to Italian identity. My informal research intensified into a full-time project in 2000 and $2001{ }^{31}$ Specifically, I was interested in how a particular class, Rome's old bourgeoisie - a category descended from the cultural and bureaucratic elite of pre-Unification, papal Rome - not only were able to re-establish their considerable status even after being shunted aside by post-Unification (1870) governments but in fact reinvented themselves as conservators of the patria, the fatherland. Shunned as pro-Vatican by Italy's post-unification governments and hence seen as a powerless ally by the Vatican, they existed in a semiotic no-man's land for several generations, until, ironically, Fascism reinvigorated the notion of patria, which became their virtual homeland. Neither elite nor proletarian, aristocrat nor middle-class, the lack of an ideologically-sanctioned status made them perfect bellwethers in the search for new identities. It is not surprising that the corruption crisis of the 1990s made them nostalgic, not for fascism's ostensible connotations of

28 Olivia Angé and David Berliner, 'Introduction: Anthropology of Nostalgia - Anthropology as Nostalgia,' in Anthropology and Nostalgia, ed. Olivia Angé and D. Berliner (New York: Berghahn, 2015), 1-2.

29 Naqvi, 'The Nostalgic Subject.'

30 For example, as seen in 'designer nostalgia', where the past is intentionally recovered by stylists as an antidote to tension in the present. See D.J. Huppatz, 'Designer Nostalgia in Hong Kong,' Design Issues 25 (2009): 14-28, https://doi.org/10.1162/desi.2009.25.2.14; Stuart Tannock, 'Nostalgia critique,' Cultural Studies 9 (1995): 453-464.

31 Guy Lanoue, Rome Eternal: The City as Fatherland (Oxford: Legenda, 2015). 
force but for the narrowness of the regime's ideological and social focus, which defined many niches in the private sphere where individuality could flourish.

Roman bourgeois were not the only class to proclaim allegiance to Rome as their fatherland. All Romans, it seemed, had some notion of the importance of Rome as the heart of an important community. It soon became evident that 'Rome' was an alternative or at least a counterweight to the modern state and its institutions. In particular, people insisted that the performative aspects of their everyday habitus - speech registers, gestures, dress, food, forms of politeness and sociality, among myriad other forms of cultural semiosis - were markers of identity and status that are more important than political power and money, which were seen as controlled by the institutional practices of the state. 'Rome' as a community obviously included people of different ranks, but its attributes were more immediately accessible to everyone, unlike notions of 'citizen' that left many people frustrated and disempowered.

It seemed people were seeing the past in two ways: the first, as a standardised, 'top-down' potted history that overrode individual memories; second, as an oblique 'bottom-up' reading based on the mise-en-scene of everyday values projected onto 'tradition'. Intrusive bureaucratic practices encourage resistance and create lacunae in which 'tradition' is no longer the personal detritus of the past that official history forgot. ${ }^{32}$ Personalised memories - some empirically verifiable according to historically-grounded narratives; others, too idiosyncratic and personal to be scrutinised - are meta-codes that insulate everyone from the impersonality and intrusiveness of institutional practices.

The spiral of mutual mistrust between rulers and ruled creates a highly fluid timescape. Italy's historical baggage, however, transforms the minutiae of 'tradition' into potent social capital that further aggravates tensions when dealing with the 'modern' state apparatus. Inevitably, personal memories hit historical bedrock and must find a way of intersecting the historical 'truths' that ideologues use to justify state practices in the name of 'modernity', especially since the state has its own official versions of 'tradition' and 'folklore' that it nourishes in textbooks and by grants to 'traditional' industries. ${ }^{33}$ While these politico-cultural initiatives are enthusiastically applauded and exploited on the local level (for example, university-educated young people in demographically-stagnant villages may try to revitalise tradition by holding

\footnotetext{
32 See Herzfeld, Cultural Intimacy.

33 Cf. Maria Manca, La poésie pour répondre au hasard: Une approche anthropologique des joutes poétiques de Sardaigne (Paris: CNRs Éditions/Éditions de la Maison des Sciences de l'Homme, 2009).
} 
various festivals that celebrate local cuisine, music, poetry and sociality), but on the other they are resented as just another example of state control.

Neither the state-sponsored culture of (alleged) merit nor the historicallysensitive fatherland exists independently, nor are their defining traits mutually-exclusive. All Italians have access to both, though individuals have different statuses and roles in each domain. Each is an imaginary construction and shares important tropes of conception and continuity. There is one crucial difference: ${ }^{34}$ social hierarchies shaped by civiltà and its traditions are in a sense timeless and out of phase with the constant ups and downs of power that define the state and its institutional practices because civiltà is attuned to things and practices that (allegedly) define everyday life from one generation to the next.

Definitions of the fatherland evolved as the post-1870 liberals failed to attach a sense of fatherland to a progressive and modern country worthy of respect abroad. The patria was presented through propaganda as a faithful embodiment of specific nationalist practices whose aim was to define Italy for the new Italian elites: 'Beginning in the 188 os, once Rome was conquered, the theme of the patria became the dominant element in the construction of the identity of the [new] Roman and Italian bourgeoisie.' ${ }^{35}$ Eventually, in the 1890 s, failure at home was in part hidden by acquiring a colonial empire to prove that the values of the patria were consistent with the new national project of unifying Italy's many divergent regions by appealing to vague notions of past Imperial glory. By the 1930s, the shabbiness of Italy's imperial project led to another shift as Fascists started providing services (health care, education, electrification) to previously-ignored segments of the polity (peasants, workers). Local organisations - eg., Opera Nazionale Balilla (youth), Gioventù Italiana del Littorio

34 Galli della Loggia also points to differing definitions and confusing legitimacies that surround the birth of these two definitions of the political community: 'The crisis in the idea of the nation in post-War Italy has its origins ... in the new republican regime's problems of legitimacy, which, vis-à-vis the war [and the actions of the resistance] put it in an impossible situation'; Ernesto Galli della Loggia, La morte della patria (Rome-Bari: Laterza, 1996), 27 (my translation). The postwar government threw out the patriotic baby of the founders of Italy along with the Fascist bathwater without offering a viable substitute. Unlike many other Italian historians who concentrate on political developments and ideological struggles, Galli della Loggia centres his analysis around these feelings of belonging. He emphasises that Italy's postwar problems stem from its ideological struggles that ignored sentiments of patriotism that had been effectively mobilised by the Fascists when they tried to link civiltà and nation.

35 Cecilia Dau Novelli, La città nazionale: Roma capitale di una nuova elite (1870-1915) (Rome: Carocci Editore, 2011), 171 (my translation). 
(youth), Opera Nazionale Dopolavoro (workers), Massaie Rurali (peasant women), Opera Nazionale ed Maternita ed Infanzia (children and mothers), Milizia Volontaria per la Sicurezza Nazionale (squadristi - members of the 'action squads'), Fasci Giovanili di Combattimento (students, youth), among others were created to give people an immediate though limited sense of participating in the regime's social and especially cultural institutions, although the multiplicity of organisations and their cross-cutting membership diluted any potential organised resistance to the regime.

In the 1950s, political sins and corruption were justified as necessary evils to unite the country and to counter the growing strength of the Communist Party. Intimate spaces became a refuge where 'real', 'uncontaminated' notions of status and hierarchy could frame people's everyday lives. Not surprisingly, the rapid political shifts of the nation were transposed, in the Fatherland, into attributes that are acquired by the repetitive, corporeal disciplining of the Self that imply transmission over time: learning 'proper' ways of eating, walking, courting, dressing, talking, and so on.

In brief, the chaos of history has transformed the past into a semiotic no man's land, whereas tradition and its virtual home, the patria, stress continuity and unity. It is no wonder that personal memories and nostalgia, in its widest sense of a longing for the emotional security of childhood, are powerful metaphors for stability and the uncontaminated self.

\section{Wartime Nostalgia}

Nostalgia for wartime is not unknown, as scholars have presented case studies that stress the emotional intensity of albeit short-lived solidarity able to transcend traditional class and ethnic enmities when faced with a common foe. It seems that every modern war has elicited some form of nostalgia, even though nostalgic memories are neither uniform nor unequivocally shared, as Summerfield's study of women in wartime Britain demonstrates: ${ }^{36}$ pre-existing social and gender-based disparities are sometimes accentuated and become anchors for subsequent social positioning. Memories of wartime, however, are almost always highly filtered, saturated with erasures and enhanced by current cultural and especially political engagements, as Hirsch and Spitzer's study of

36 Penny Summerfield, Reconstructing Women's Wartime Lives: Discourse and Subjectivity in Oral Histories of the Second World War (Manchester: Manchester University Press, 2008). 
Holocaust testimony suggests. ${ }^{37}$ Nor are these memories inevitably associated with nostalgia. It does not seem to matter if the homeland was a battlefield or not; ${ }^{38}$ wartime nostalgia seems just as powerful in devastated countries as in others that were spared direct involvement. ${ }^{39}$ For example, wartime nostalgia (elsewhere, 'imperialist nostalgia'40) has been reported for the South African apartheid regime, ${ }^{41}$ here used in the sense of melancholy, mourning and grieving as a way of dealing with social trauma, or in the sense of longing for the social cohesion of the Stalinist past ${ }^{42}$ and of the former Soviet Union, ${ }^{43}$ where conditions in the period 1920 to 1945 were unarguably worse than in Italy.

Unlike the former Soviet Union, however, where enemy brutality fed feelings of patriotic fervour, no clear sides emerged in the Italian case. Major battles were fought as much between Italians as with foreigners; unknown, though high, numbers of civilians were killed by all sides; what was arguably Italy's only (albeit politically compromised) symbol of unity, the Crown, was

37 Marianne Hirsch and Leo Spitzer, 'The Witness in the Archive: Holocaust Studies/ MemoryStudies,'MemoryStudies2(2009):151-170,https://doi.org/10.1177/1750698008102050.

38 As witnessed in nostalgia for the (alleged) security of communist rule in Romania in the analysis by Van Assche of memory and forgetfulness in the Danube delta region; Kristoff Van Assche et al, 'Forgetting and Remembering in the Margins: Constructing Past and Future in the Romanian Danube Delta,' Memory Studies 2 (2009): 211-234, https://doi. org/10.1177/1750698008102053.

39 See Clarke's analysis of nostalgia and the American Civil War: Frances Clarke, 'So Lonesome I Could Die: Nostalgia and Debates over Emotional Control in the Civil War North,' Journal of Social History 41 (2007): 253-282; Bissell's examination of colonial nostalgia: William Cunningham Bissell, 'Engaging Colonial Nostalgia,' Cultural Anthropology 20 (2005): 215-248; Roper's description of nostalgia and the Great War: Michael Roper, 'Nostalgia as an Emotional Experience in the Great War,' The Historical Journal 54 (2011) :421-451; Hollow and World War II: J. Hollow, 'That Life, That Death: A Nostalgia for Nostalgia,' The Iowa Review 26 (1996): 172-182; Clapperton on the siege of Leningrad: James Clapperton, 'The Siege of Leningrad as Sacred Narrative: Conversations with Survivors,' Oral History 35 (2007): 49-6o.

40 Renato Rosaldo, 'Imperialist Nostaglia,' Representations 26 (1989): 107-122. Special Issue: Memory and Counter-Memory.

41 Norman Duncan, Garth Stevens and Christopher Sonn, 'Of Narratives and Nostalgia,' Peace and Conflict:Journal of Peace Psychology 18 (2012): 205-213, http://dx.doi.org/10.1037/ aoo29533.

R.G. Gidadhubli, 'Looking Back on Stalin,' Economic and Political Weekly 38 (2003): 1554-1555.

43 Serguei Alex Oushakine, “We're Nostalgic but We're not Crazy": Retrofitting the Past in Russia,' Russian Review 66 (2007): 451-482. 
irremediably tarnished when the King fled Rome in 1943; towns were destroyed by allies as much as by enemies; Allied bombing killed thousands of innocent civilians but were strangely seen as a welcome prelude to the end of the Fascist regime. ${ }^{44}$ The best efforts of postwar historical revisionism failed to sort out the mess, except by burying everything tinged by fascism, including its positive accomplishments. ${ }^{45}$

On the individual level, the situation was too chaotic to establish unequivocally a single, idealised myth of the family home as an emotional Heimat. ${ }^{46}$ If the Allies' wartime propaganda could dehumanise the Nazis as robot-like killers, if Nazis could portray Russians as primitive brutes intent on raping women and killing children, Italians were caught in a much more complex image war. Even after the war, Italian suffering in the end could not be justified or explained away by appealing to higher sentiments, that suffering was all in the name of liberty, combatting tyranny, democracy or saving the Jews. On the contrary, (most) historians and private accounts of the ventennio agree on Mussolini's megalomania, the pathetic attempt to gain colonial status by attacking Abyssinia, the ill-equipped Italian army falling victim to the brutal Russian winter when they were sent to fight Russians as allies of the Germans, the regime's use of castor oil to literally purge its political enemies, and so on. In sum, there are few redemptive qualities to Italy's wartime past to which nostalgia can be anchored.

44 Cesare De Simone, Venti angeli sopra Roma: I bombardamenti aerei sulla città eterna (il 19 luglio e il 13 agosto 1943) (Rome: Mursia, 2007).

45 See for example Cossu's analysis of how the intricacies of wartime Resistance, which had been fuelled by catholics and communists, right and left, became fused into a single heroic myth attached to the Communist Party, the 'dominant cultural entrepreneur of the memory of the Resistance' Andrea Cossu, 'Commemoration and Processes of Appropriation: The Italian Communist Party and the Italian Resistance (1943-48),' Memory Studies 4 (2011): 387, https://doi.org/10.1177/1750698011408183.

46 Although Millo Diana's collection of sixteen (by-now) grandmothers' childhood memories of wartime in Naples and Rome does adhere to the standard canons of nostalgia for wartime emotional closeness and mutual help, the individual stories are written by members of the aristocracy or upper bourgeoisie. Their memories of being forced to seek refuge by moving among their various palaces in the city and estates in the countryside, and their privileged access to black market food and loyal servants cannot be considered typical. Most even had a German nanny and quite a few could speak German; two families hosted the royal court in their flight from Rome to Brindisi in 1943. Olga Millo Diana, ed., La guerra e le bambine: Sedici nonne raccontano (Naples: Edizioni Scientifiche Italiane, 2014). 
There is a parallel in Bartmanski's analysis of post-communist nostalgia in the Eastern Bloc, ${ }^{47}$ in which he shows that images of the past can act as a bridge linking the communist past to a radically different (and jarring) present. But unlike twentieth century communist regimes that were allegedly liberalised in the 1990s, Italy has a huge historical chip on its shoulder. Although it is tempting to agree with Baudrillard's notion of nostalgia as a loss of historicity, ${ }^{48}$ this cannot account for attempts to recover the past by anchoring significant individual memories to Nazi occupiers or Fascist oppressors. The descriptions I recorded are not attempts to recover the negative past but to construct a workable present by stressing banal but key events that validate everyday values.

\section{4} Narratives

As mentioned earlier, I engaged in hundreds of conversations regarding Roman identity. The stories I present here were not elicited as answers to questions about wartime and nostalgia. They were offered spontaneously, which in hindsight is perhaps not so unusual when one considers the amount of lost and found historical baggage in Rome. They are not representative, especially since I am not sure that Rome could ever be represented by an objectively selected sample. I knew most of the narrators well before these stories came up in conversations about other and sometimes very banal themes. I was not specifically asking about the past. At first, I thought people were personalising the interview situation. At first, I did not attach too much importance to them. As a 'professore' and 'dottore', I had come to see interactional strategies that tried to level status differences as normal. It was only with hindsight that I realised that status differences were not at play, since I was dealing with members of the bourgeoisie. It was only later that I began to see common threads and themes, and to understand the urgency with which they were told.

I also realised that people were not evoking the hardships and moral ambiguities of Fascist Italy to glorify their cunning and ability to survive. Many people volunteered details that evoked humour, warmth and humanity (and its frailty): how a Fascist highly critical of bourgeois privilege nevertheless stuffed himself when invited to a bourgeois family feast consisting of black market delicacies; how someone got sick from eating too many eggs because,

Dominik Bartmanski, 'Successful Icons of Failed Time: Rethinking Post-Communist Nostalgia,' Acta Sociologica 54 (2011): 213-231.

48 Jean Baudrillard, The Illusion of the End (Cambridge: Polity Press, 1994). 
suddenly, they had come across a windfall supply that they did not want to share; how a sick peasant repaid a doctor for (free) treatment by offering him the only resource he had, asking him to be godfather to his child; how Fascists (Party members and sympathisers) hid Jews because they were family friends; how pampered bourgeois women were transformed into chauffeurs, messengers and even fighters for the underground.

I began to realise that these anecdotes were important framing devices. More to the point, Nazis and Fascists were portrayed not as antagonists responsible for the war and its hardships that allowed people to shine as heroes against adversity but as protagonists whose individual actions defined fleeting but pivotal personal moments that were not otherwise easily framed by current popular discourses, in the 1990s and beyond, which had become poisoned as more and more state-enabled corruption came to light. While other wartime nostalgia narratives stress how 'we' and 'I' come together by means of mutual help and shared experiences, these personalised narratives are not articulated around hardships. The literature did not help me understand how the 'enemy' could be portrayed in neutral or even positive terms, especially since I knew that the narrators had not been collaborators or sympathisers.

Nor were these personal stories offered to excuse or cover past or present sins. In some cases, people had no direct experience of the war but were relating the fallout of their parents' wartime experiences. In contrast, when in other contexts I specifically asked people about the past, Nazis and Fascists were universally denounced as cold and vindictive by the same narrators (Fascists especially, whose lower class origins were alleged to have motivated their cruelty in their interactions with high-status people).

There was another puzzle: people began talking about the past while we were discussing what Rome meant today. Against the backdrop of almost universal denunciations of Italy as a failed, corrupt nation, people would offer these stories where, seemingly, it was possible for even Fascists and Nazis to ignore political divisions and interact on a 'normal' basis of shared culture: food, love, humour, getting a job. People were building symbolic bridges that linked the institutional and the intimate by ignoring the main narrative of enemy antagonism in favour of small, telling details that, in effect, framed miniature morality tales: if wartime enemies could come together even for a moment, it was because they could go beyond official roles and reach into the culture of the intimate. If it had happened in the extreme conditions of war, it could still easily happen today, despite state corruption and inefficiency.

The stories I collected are not examples of collective memory; I share Berliner's reservations on the imprecise theoretical nature of the concept and its 
unspecified links to collective identity. ${ }^{49}$ Remembering is individual and becomes 'collective' only when others already share the same particular frame of reference. This nuance becomes important in cases such as Italy, where wartime nostalgia for 'the enemy' is certainly not part of any public discourse that leads to, 'identity creation, emotional bonding, therapeutic healing, and directive instruction' or to 'a dynamic cultural practice that sustains the cultural continuity of a community and in the meantime adapts to the cultural transformation of the community in a historical era., 50

Furthermore, the trope of 'home' as a refuge from war is strikingly absent. The events are mostly outside, in public: a kind German officer allows a young suitor to pass a roadblock to see his fiancée in the country yet executes two Italian partisans; a German soldier gives a young peasant (the narrator) a piece of chocolate, an act that underscores his poverty and drives him to hide in the basement to avoid sharing any with his friends; Nazis are physically absent though still an unpleasant presence when a boy's family teases his mother for her son's blonde hair and blue eyes (placing him, inadvertently, in a central role in decades-long family dynamics and myth-making); Nazi mistreatment of a pow leads to an episode of imaginary nostalgia for an unseen Canadian 'home' the Italian officer has only 'seen' through the sad graffiti left by a previous prisoner ('oh, que je rêve la neige du Canada'); Fascist expropriation of a bourgeois neighbour's land gives a morally corrupt proletarian a head start in life (and, out of a feeling of cussed contrariness, leads him to hide Jews from Nazis, which allows his left-leaning bourgeois godchild to partially reconcile herself to his corrupt practices), which leads to a plush position in the bureaucracy where he pulls strings as much for his bourgeois goddaughter as to affirm that he, the upstart proletarian, has arrived. Other Nazis brutalise Italian Pows; although Germans are merely a plot device when a six-year old boy in the 1950s blurts out on a tram that his blonde hair and blue eyes are from the German occupiers of Rome, there is real danger to his mother when postwar hatred of Fascists and Nazis still ran hot; and while Fascists are only background players who enable a woman's corrupt godfather's rise to fortune, they are nonetheless responsible for threats to her family's status quo when her pro-monarchist, anti-Fascist father loses his government contracts. 'Maria' is painfully aware

49 David Berliner, 'The Abuses of Memory: Reflections on the Memory Boom in Anthropology,' Anthropological Quarterly 78 (2005): 197-211; W. Hirst and D. Manier, 'Towards a Psychology of Collective Memory,' Memory 16 (2008): 183-200, https://doi.org/10.108o/ 09658210701811912.

50 Qi Wang, 'On the Cultural Constitution of Collective Memory,' Memory 16 (2008): 313, 315, https://doi.org/10.108o/09658210701801467. 
that her story is an allegory for the downfall of her class at the hands of people like her social-climbing godfather, a blackmailer who made his fortune by paying prostitutes for compromising information and whose parent's 'peasant' fertility (as she called it) allowed them to obtain a neighbouring estate expropriated from a disgraced monarchist. There is no mention of kindness, solidarity or intimacy when a deranged taxi driver praises Mussolini not only for 'making the trains run on time', as the old saying goes, but for actually engineering a train. Here, the trope of horizontal movement 'on time' seems to stand for the vertical social bump up the status ladder enjoyed by Mussolini's lower-middle class supporters. Finally, one narrative stresses that Nazis sent captured Canadian Pows to a Fascist air force base where they became the Fascist commander's only friends after his previous human contacts with Abyssinians were compromised because he had been ordered to bomb the very people to whom he was drawn.

In brief, during the difficult 1990s, people were not invoking the warmth of a mythified version of their childhood. They were cultivating tiny gardens of closeness and humanity in the cracks of the state-sponsored hate that underlay public discourse in the 1930 and 1940s, using the overwhelming presence of war to underscore their distance from the distrust and confusion that had become normal in the 199os. Here, innocent, everyday objects and practices of the past became milestones of self-realisation in the present: a young boy eating a piece of German chocolate makes him aware he lives in a world of envy and class discrimination; riding a bicycle to visit a fiancée creates a chance encounter with a sympathetic Nazi officer, which leads him to debates on the merits of Mozart, which reinforce his commitment to bourgeois values; a chance comment on a tram sets in place a generation of interpersonal dynamics that ultimately establish that the young child's temporary leading role will be transformed into adult self-assurance; a pow dreaming of an idyllic postcard image of a snowy Canadian village becomes a metaphor for all that is pure and uncorrupted; sharing a joke with a Canadian Pow reinforces the independence of an Italian officer from his Fascist superiors and ultimately leads him to reconnect, fifty years later, with a humble cook; a mother's fertility ultimately ensures that her son's little chats with prostitutes will establish his power forty years later, which he can use to benefit his niece despite their diametrically opposing ideological and political positions.

The emotional and moral distance that these stories establish is not only metaphorical: the fiancé's story is anchored in a quasi-heroic sixty kilometre bicycle journey in German occupied zones; 'Domenico's' first taste of chocolate is foreign; 'Pietro' is imprisoned in Austria and finds solace in the image of a snowy Canada that he would never see; 'Sergio' explains his presence in 
his former cook's chop by reminiscing about his friendly contact with Canadian Pows in Abruzzo, his Abyssinian friends, and his postwar life in Nigeria. His only friends are strangers: Abyssinians (though they were formally his enemies) and Canadian Pows (though they were formally his prisoners). The Fascist state is the enemy: they force him to bomb the people he admires and end to his friendship with Canadians. He does not mention friendships in his postwar life in Nigeria but does state that he worked as a surveyor who moved from place to place. Even when he comes 'home' to Sergio's cafe, he realises that they are both exiles from their Italian home towns and can only be friends in the city where they were brought together by the Fascist war machine. While 'Maria' frames her story in terms of moral distance (she explicitly distances herself from her godfather's corruption and peasant origins by mentioning her family's privileged access to the Vatican, a 'traditional' benefit that the corrupt godfather cannot attain because of his lowly social origins and greasy connections), it seems significant that she takes pains to mention that the bonds that brought her father and godfather together took place in the countryside, away from their main Roman residences where their geographic closeness would not have overcome the social distance that separated them.

Maria is framing her life by talking about another person's wartime experiences, her godfather, and how his life intersected with Fascist ideals; involuntarily because the Party rewarded him for his parents' many children, but also with a voluntary dimension, it is implied, because his self-serving corruption is evocative of contemporary political practices, at least in Maria's genteel mindset. In sum, Maria stresses the social distance of class and political barriers (her godfather is a 'Fascist') to offset the geographic closeness of being neighbours in the countryside, a point she implicitly acknowledges and explicitly stresses because her blameless bourgeois life of good manners is in fact inextricably linked to the dirty undercurrents of the ventennio that eventually allowed her corrupt godfather to gain power and money and eventually launch her career.

It is noteworthy that there is no longing for the intimacy and innocence of childhood that evokes mother's cooking or family holidays. There is no wistful quality of lost comforts, psychic or otherwise. Families and friends are absent or in ambiguous roles: poverty forces a young boy to hide from his friends to eat his chocolate alone; 'Francesco's' mother threatens to slap him when as a six-year old he publicly proclaims that his blonde hair was because of his mother's relationship with the Germans; the Pow is separated from the men under his care because of his rank; the base commander can only relate to the pows; the fiancé's parents cannot seek refuge in the countryside, forcing him to visit his evacuated girlfriend; Maria's father loses his job because of Fascists. These stories hinge on the failure of normal institutional arrangements: a taxi 
ride with a foreigner turns into an opportunity to expound a political thesis on Mussolini's good points that no Italian can officially acknowledge. The failure of institutional arrangements creates a void for projecting alternatives, imagined and real.

Although I am addressing exchanges and opinions in the 1990s that were launched by the fall of the corrupt postwar alliance, Italians still live in a state of psychic siege laid by the state, creator of a myriad of intrusive, incoherent and arbitrary laws, inefficient and corrupt practices, and, recently, enabler of racist attitudes and naked aggression towards the disempowered. ${ }^{51}$ Citizens feel unprotected by institutions and by political practices; worse, they are unprotected from the nation's institutions and political practices. With no single charter myth to give it legitimacy ${ }^{52}$ and, more importantly, incapable of enabling an acceptable model of the self-governing Foucauldian citizen, the semiotically sterile state tries to mold the most mundane aspects of everyday life into its image. Everyone pays the price of confusion: resources and time are wasted on endless nitpicking; essential social services are delivered in a sporadic and arbitrary fashion and so are no longer seen as an automatic right of the citizen but as a payoff for conformity and political docility; civil servants caught in a morass of contradictory laws and tacit political pressures become paralysed and are criticised not only by the public but by their own managers.

It is not surprising that the confused pathways in state-sponsored culture point people to prefer the simple markers of everyday life as reference points, nor is it surprising the origins stories of traditions are framed by the rosy glow of nostalgia for a time when things were organised. But that is not the only dimension involved: throughout all these stories, people seem to be yearning for the Fascist regime's heavy hand merely as a preliminary backdrop for their 'real', 'human' stories - Fascism almost as a theatrical prop. The ubiquitous

51 In October 2018 the mayor of Riace, Domenico Lucano, was arrested for hosting refugees in his city.

For example, Italy has many dates that mark its foundation as a political entity. Galli della Loggia names three, none of which are officially recognised: 1922 (Mussolini's March on Rome), 1948 (Birth of the Republic), 1994 (Berlusconi's first rise to power). Italy was founded in 1861, 'consolidated' in 1870 with the conquest of Rome, liberated from Fascism in 1944, etc. Ernesto Galli della Loggia, Tre giorni nella storia d'Italia (Bologna: Il Mulino, 2010). 
presence and imposition of allegedly highly-organised ways of life, rules and structures defines many lacunae in which people can express their individuality. Paradoxically, the regime's public heavy-handedness helped consolidate private and intimate spaces where agency flourished.

Within this hostile framework of contemporary Italy, there is a metaphoric shift to another time, to another place, to another community, that allows individuals to reconnect to everyday lives that are not in fact 'everyday' and certainly not rosy: it is wartime, or nearly so. In war, nothing is mundane, so people cobble together memories with the bric-à-brac of suffering and triumph in the past as a substitute for civiltà made unattainable by the corrupt nation in the present: a piece of chocolate secretly hoarded; a bicycle ride that allows a young Italian boy to chat about music and women with German soldiers; a mother's shame at her boy's innocent allusions to German parentage; ghostly messages about Canada that a former prisoner carved into a bunk now occupied by an Italian officer in 1944; playing cards with 'the boys'; hotel prostitutes become the basis for an illicit fortune that allows genteel 'Maria' to get her first job and, more importantly, to construct a social narrative where she, a well-bred bourgeois, and her godfather, a corrupt cynic, whose social climbing acrobatics would place him at the opposite end of her scale of values, are nonetheless brought together in the same community. It is not the usual wartime descriptors - fear, violence, and uncertainty - that unite people, but the banal gesture that cuts across the standard institutional divisions of nation and class. In other words, people are framing nostalgia narratives in which rosy details of self-creation are enabled by geographically and socially distant others acting more or less as 'normal' people should: free, of only for a moment, of their official roles. Trivial things and events triggered by 'the enemy' become frameworks that help establish havens for individuality and community otherwise threatened by the spectacular black holes in officially-sanctioned discourses. People harken back to wartime, when normal state institutions were suspended, and to an ethnic and political Other whose distant origin and menacing character are guarantees that the seminal but haphazard events they set in motion will be uncontaminated by the postwar Nation. 